Portland State University

PDXScholar

1972

\title{
Mutual exclusion between Salmonberry and Douglas-fir in the Coast Range of Oregon
}

Kenneth Ray Still

Portland State University

Follow this and additional works at: https://pdxscholar.library.pdx.edu/open_access_etds

Part of the Ecology and Evolutionary Biology Commons, Forest Biology Commons, and the Plant Biology Commons

Let us know how access to this document benefits you.

\section{Recommended Citation}

Still, Kenneth Ray, "Mutual exclusion between Salmonberry and Douglas-fir in the Coast Range of Oregon" (1972). Dissertations and Theses. Paper 963.

https://doi.org/10.15760/etd.963

This Thesis is brought to you for free and open access. It has been accepted for inclusion in Dissertations and Theses by an authorized administrator of PDXScholar. Please contact us if we can make this document more accessible: pdxscholar@pdx.edu. 
AN ABSTRACT OF THE THESIS OF Kenneth Ray Still for the Master of Science presented June 12, 1972.

Title: Mutual Exclusion between Salmonberry and Douglas-fir in the Coast Range of Oregon.

APPROVED BY MEMBERS OF THE THESIS COMMTEE:
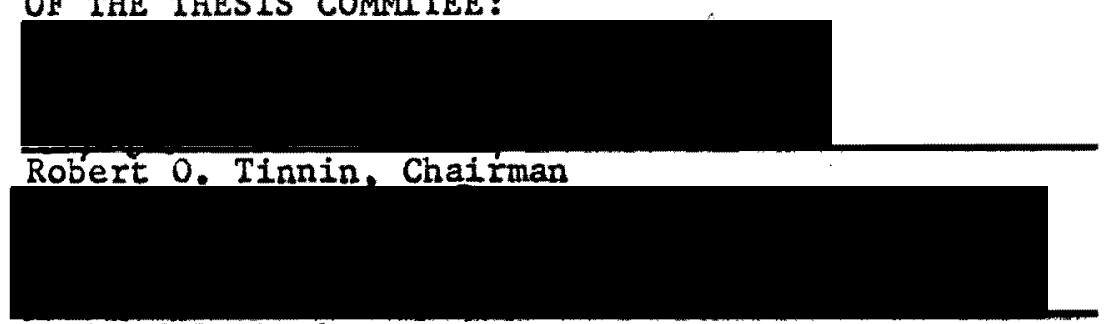

Richard D. Tocher

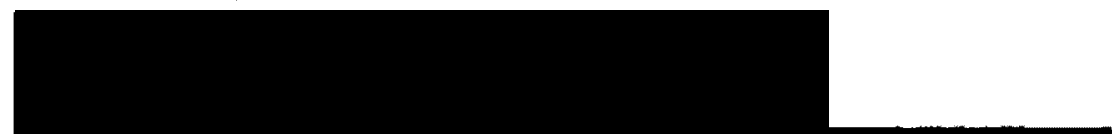

Clyde $x$, Calvin

One serious problem faced by the forest Industry in the Pacific Northwest is poor regeneration of commercial trees on land which is harvested and subsequently dominated by brush species. In Coastal Oregon, salmonberry is one of these brush species. Detalled investigations of field sites indicate that light intensity in the brush stands was low but sufficient for germination and early growth of Douglas-fir seedlings and soil moisture percentages and nutrient levels were high enough to support early Douglas-fir growth. Laboratory tests demonstrated the presence of leachable phytotoxins in the leaves of salmonberry. The hypothesis resulting from this study is that salmonberry releases a phytotoxin that in synergism with environmental stresses (i.e., light), suppresses germination and growth of Douglas-fir seedlings in the field. 
MUTUAL EXCLUSION BETWEEN SALMONBERRY AND

DOUGLAS-FIR IN THE COAST RANGE OF OREGON

by

KENNETH RAY STILL

A thesis submitted in partial fullfillment of the requirements for the degree of

MASTER OF SCIENCE

in

BIOLOCY

Portland State University

1972 
TO THE OFFICE OF GRADUATE STUDIES:

The members of the Committee approve the thesis of Kenneth Ray Still presented June 12, 1972.

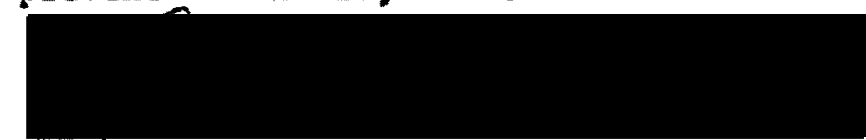

Robert 0. Tinnin, Chairman

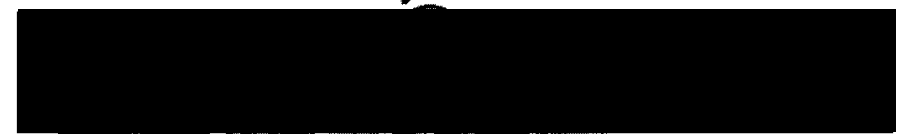

Richard D. Tocher

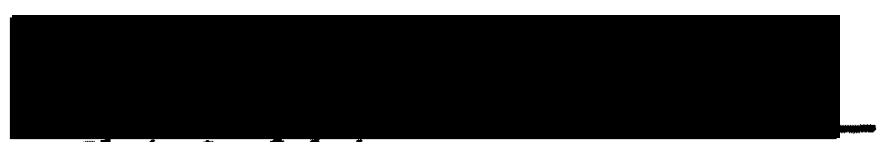

Clyde $/$. Calvin

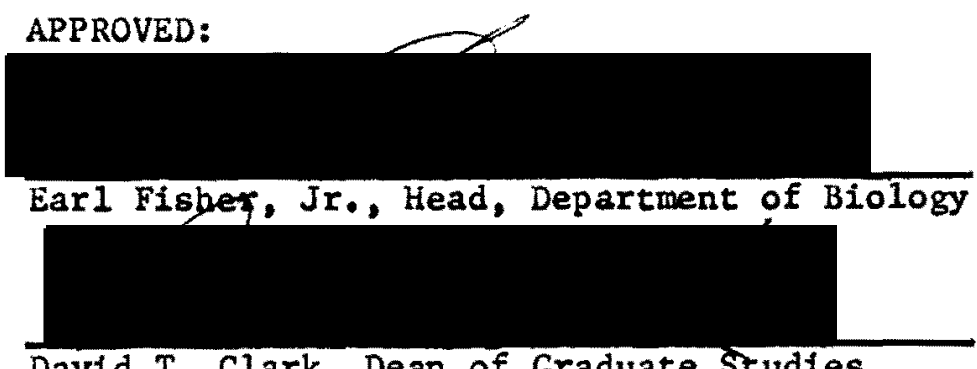

David T. Clark, Dean of Graduate Studies

June 14, 1972 


\section{ACKNOWLEDGMENTS}

The author wishes to thank Dr. Robert 0 . Tinnin for his generous guidance and encouragement as research and thesis advisor; Dr. Quentin D. Clarkson for his advise on the statistical analysis of the data; Dr. Donald Malmberg and Crown Zellerbach Corporation for use of their forest lands; Dr. Earl Fisher Jr. and the Biology Department of Portland State University for their financial support; and especially my wife, Pamela, for various forms of assistance. 
TABLE OF CONTENTS

\section{PAGE}

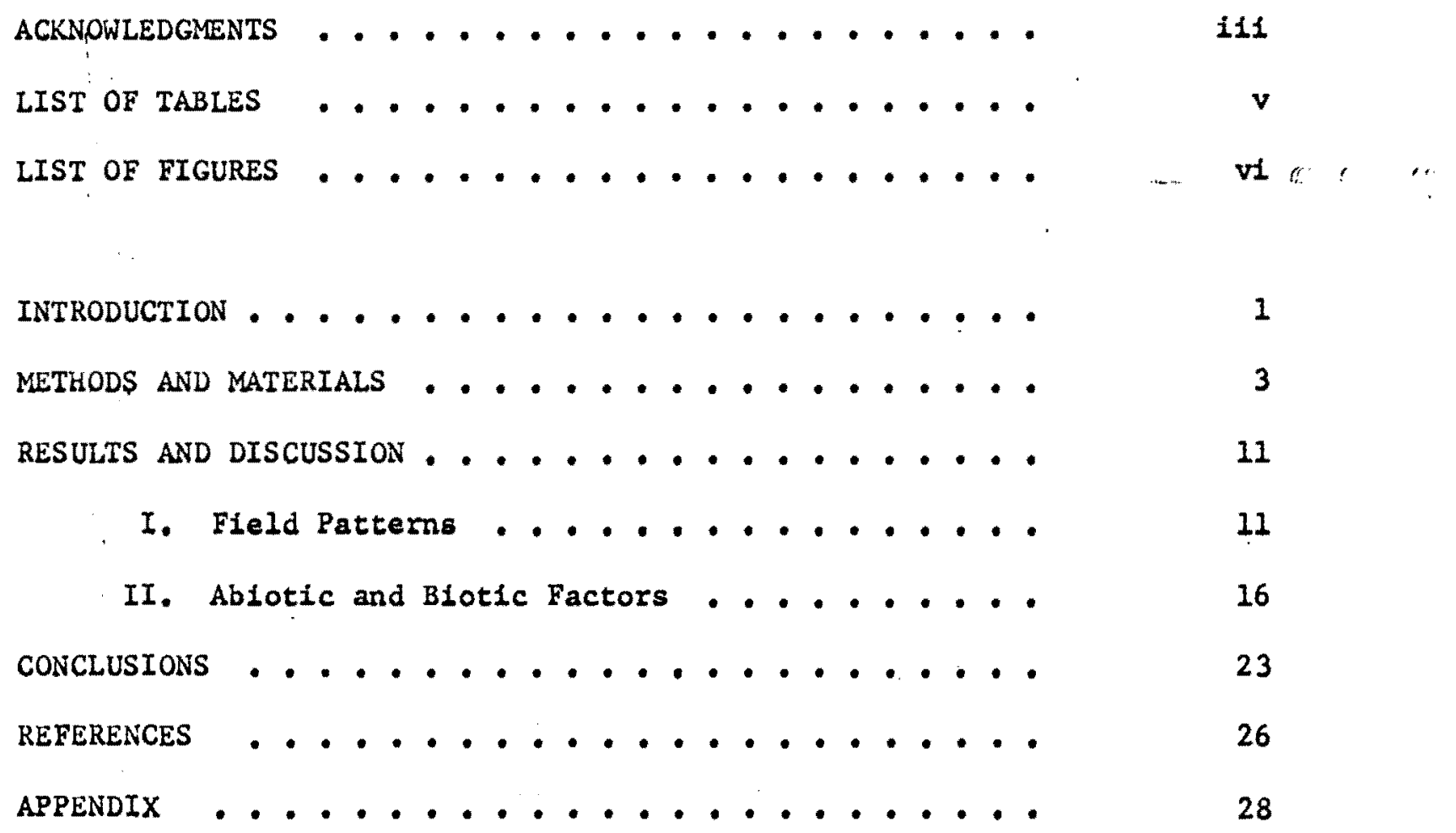




\section{LIST OF TABLES}

TABLE

PAGE

I Stem Density of Major Plant Species .......

12

II Comparison of Various Physical Factors . . . . 14

III Quantitative data on Soll Nutrients . . . . 17

IV Bioassay Data on Raphanus sativa . . . . . . 20

V Bioassay Data on Bromus tectorum ......... 21

VI Bioassay Data on Pseudotsuga menziesil . . . . 22 


\section{LIST OF FIGURES}

1 Widely spaced salmonberry plants in recently logged clear-cut. Associations between Douglasfir and salmonberry at this stage occur frequently. . .

2 Area with no bare spaces between salmonberry plants. The only Douglas-fir found in these stands have a crown higher than the salmonberry canopy . . .

3 Area showing continuous salmonberry coverage and a distinct stand boundary. ..............

4 A mixed alder/conifer stand. Openings occur between the salmonberry clones which support other plant species including Douglas-fir. . . . . . . . 


\section{INTRODUCTION}

In Oregon there are thousands of acres of potentlal forest land that are covered with dense brush (Moravets, 1951; Hayes, 1959). Interference (as used by Muller, 1969) from brush and herbaceous vegetation Is one of the more serious causes of suppressed natural establishment of commercial timber trees (Grotkowski, 1961; Ruth, 1967).

West of the crest of the Coast Range in northern Oregon one of the major'brush species is salmonberry (Rubus spectabilis). 1 This ubiquitous shrub successfully Invades cleared areas to form mono-specific stands. When salmonberry is a normal component of forested areas the shoots and roots are cut and disturbed during logging operations. By the next growing season these plants undergo vigorous resprouting from rhizomes and by suckers and establish severe competitive associations with natural or planted conifers. Soil disturbance and increased light resulting from logging operations stimulate germination of salmonberry seeds that are lying dormant in the duff (Krygier and Ruth, 1961).

The extent that salmonberry affects germination, survival, and succession of Douglas-fir (Pseudotsuga menziesii) in the coniferous areas of Oregon and Washington has yet to be determined. Preliminary experimentation has revealed only that there are detrimental effects caused by salmonberry (Morris, 1958; Ruth, 1956; Gratkowsk1, 1961).

\footnotetext{
lolant species names follow Peck, 1961.
} 
One aspect of interference which has not been considered is a biochemical interaction between salmonberry and conifers. Allelopathic interactions have been shown for a number of plant specles to have detrimental effects to the point of exclusion of adjacent vegetation (Muller, 1966; Whittaker, 1970). From one member of the genus Rubus, raspberry (‥ idaeus) the growth Inhibitor salicyclic acid has been isolated and identifled (Doby, 1965). This phenolic acid has been indicated as an allelopathic agent in several studies (Garb, 1961; DeBe11, 1970). Salmonberry has shown phytotoxicity in laboratory tests but has failed to show conclusive field interference (del Moral and Cates, 1971). One of the conifer species that is affected by salmonberry in Oregon is Douglas-fir. Salmonberry/Douglas-fir associations on clear-cut fields occur in a variety of patterns. In certain areas it appears that young seedlings of both specles can exist side-by-side. In fact, it has been observed that Douglas-fir seedlings are occasionally harbored at the base of salmonberry shrubs. However, it has been noted that these associations usually occur when there is a very small number of salmonberry shrubs and when the Douglas-fir seedlings are exposed to direct light for part of the day. As the salmonberry stands begin to mature, the number of Douglas-fir seedlings found in close proximity begin to decrease, and at maturity salmonberry stands harbor no Douglas-fir beneath the canopy. Salmonberry apparently provides a deleterious factor to the growth of Douglas-fir, and has been adjudged by many workers to be the source of severe competition. However, the specific type of competition has never been worked out. The purpose, of this study, therefore, is to determine precise field pattern for salmonberry/Douglas-fir associations and possible explanations for their cause and existence. 
METHODS AND MATERIALS

Ten study sites were selected in the Oregon Coast Range between the towns of Nehalem to the south, Astoria to the north and Elsie to the east. Elevations ranged from 305 meters near Astoria to 671 meters on Sugarloaf Mountain. Sites were selected based upon the following criteria: (1) the density of salmonberry ranging from 0-50 stems per $\mathrm{m}^{2}$; sites were chosen in which there were widely spaced areas between clones and areas with no bare spaces between clones (figs, 1 and 2). (2) Sites were selected in which salmonberry clone coverage was continuous over a minimum of 1 ha. Once these were found, classification was based upon whether the canopy was broken, allowing direct sunlight to reach ground level, or unbroken, thereby allowing no direct light beneath the canopy level. Salmonberry stands were also selected which showed a distinct boundary (fig. 3). (3) Height of salmonberry clones and individual Douglas-fir seedlings was carefully observed. Areas were selected in which a continuum of salmonberry helght ranged from a minimum of $5 \mathrm{~cm}$ (the seedling stage) to 3-4 meters (the mature stage). Areas were selected in which Douglas-fir height ranged from $3 \mathrm{~cm}$ minimum to $10 \mathrm{~m}$ maximum. (4) No site was chosen in which seed producing Douglas-fir trees were more than one-fourth mile away. (5) Clear-cut areas were selected which had been logged 3-15 years earlier. Forested areas selected consisted of mixed red alder (Alnus rubra)/Douglas-fir, pure alder, and pure Douglas-fir stands (fig.4). Once sites were located, they were gridded off into one thousand $10 \mathrm{~m} \times$ Im plots of which the marginal plots served as a buffer strip. From the 784 remaining plots, eight were then randomly chosen for study. 


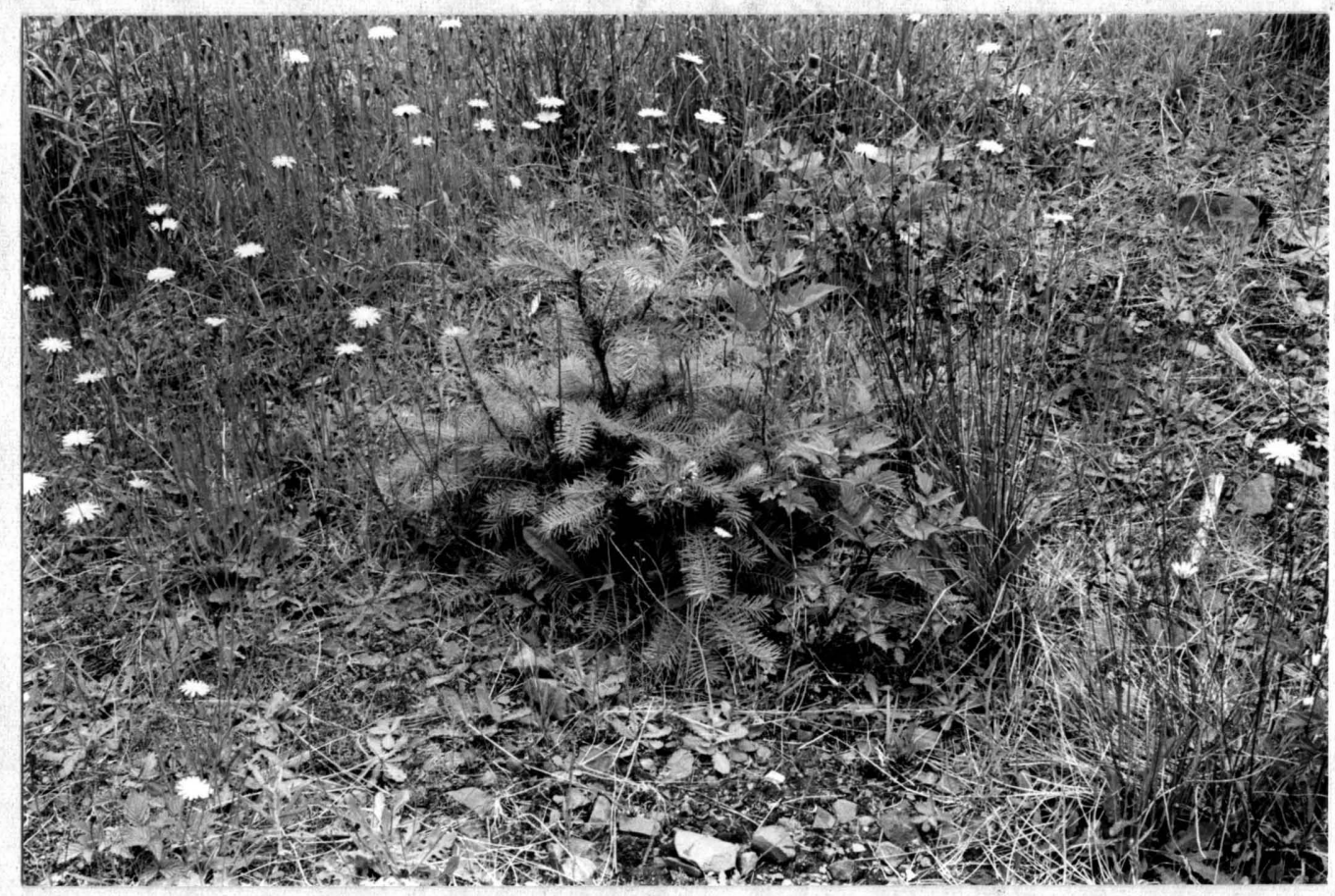

Figure 1. Widely spaced salmonberry plants in recently logged clear-cut. Associations between Douglas-fir and salmonberry at this stage occur frequently. 


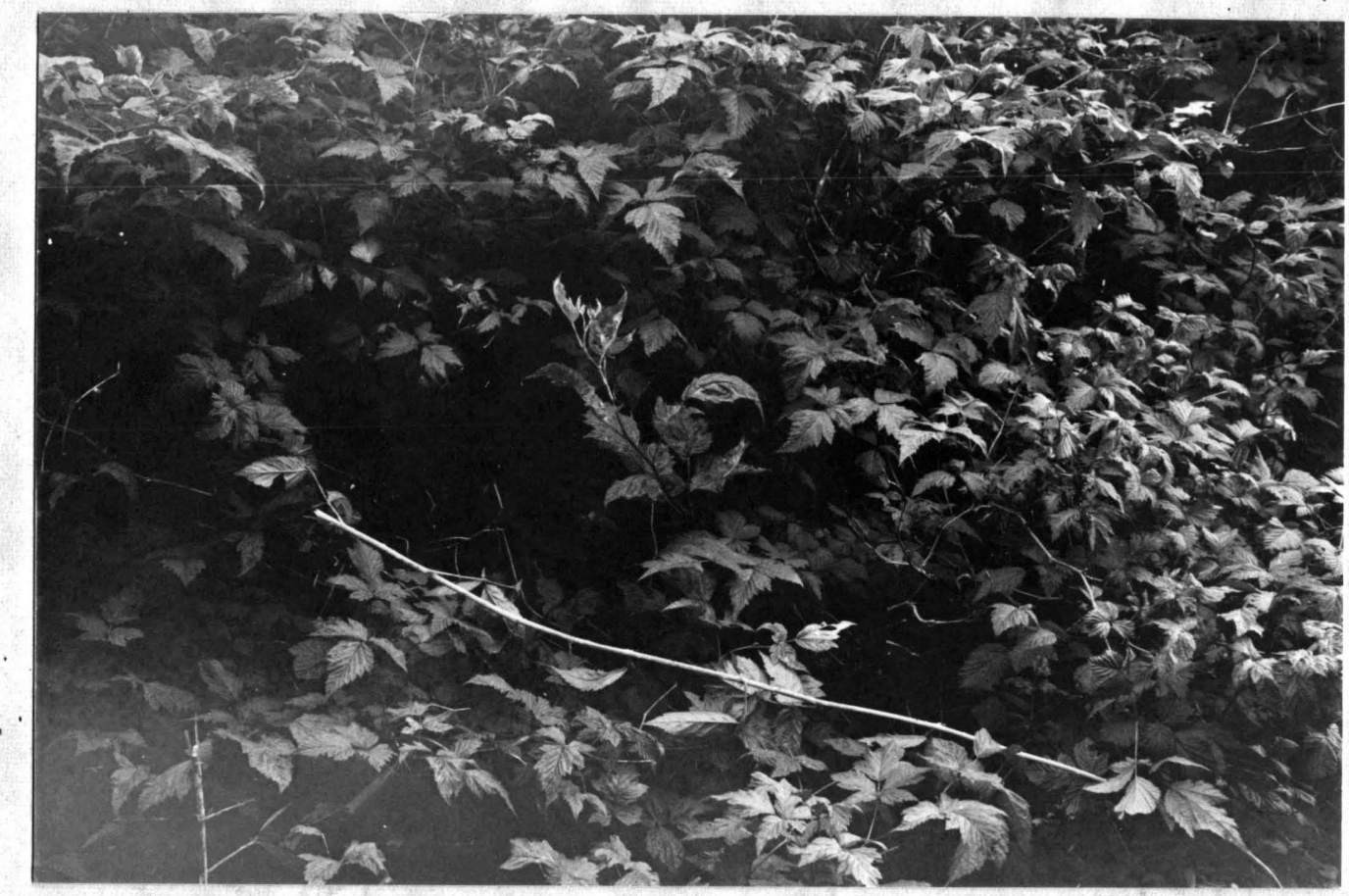

Figure 2. Area with no bare spaces between salmonberry plants. The only Douglas-fir found in these stands have a crown higher than the salmonberry canopy. 


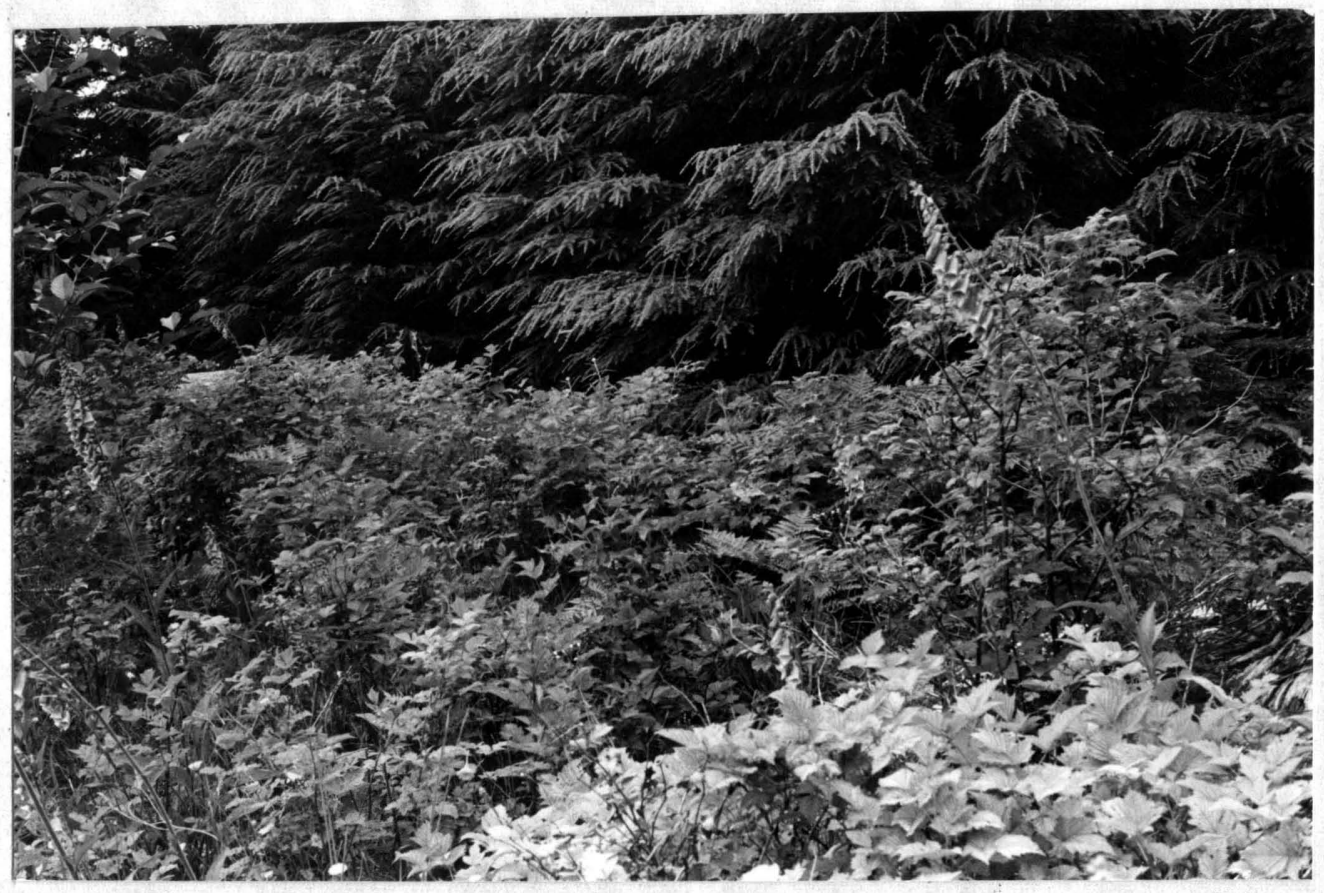

Figure 3. Area showing continuous salmonberry coverage and a distinct stand boundary. 


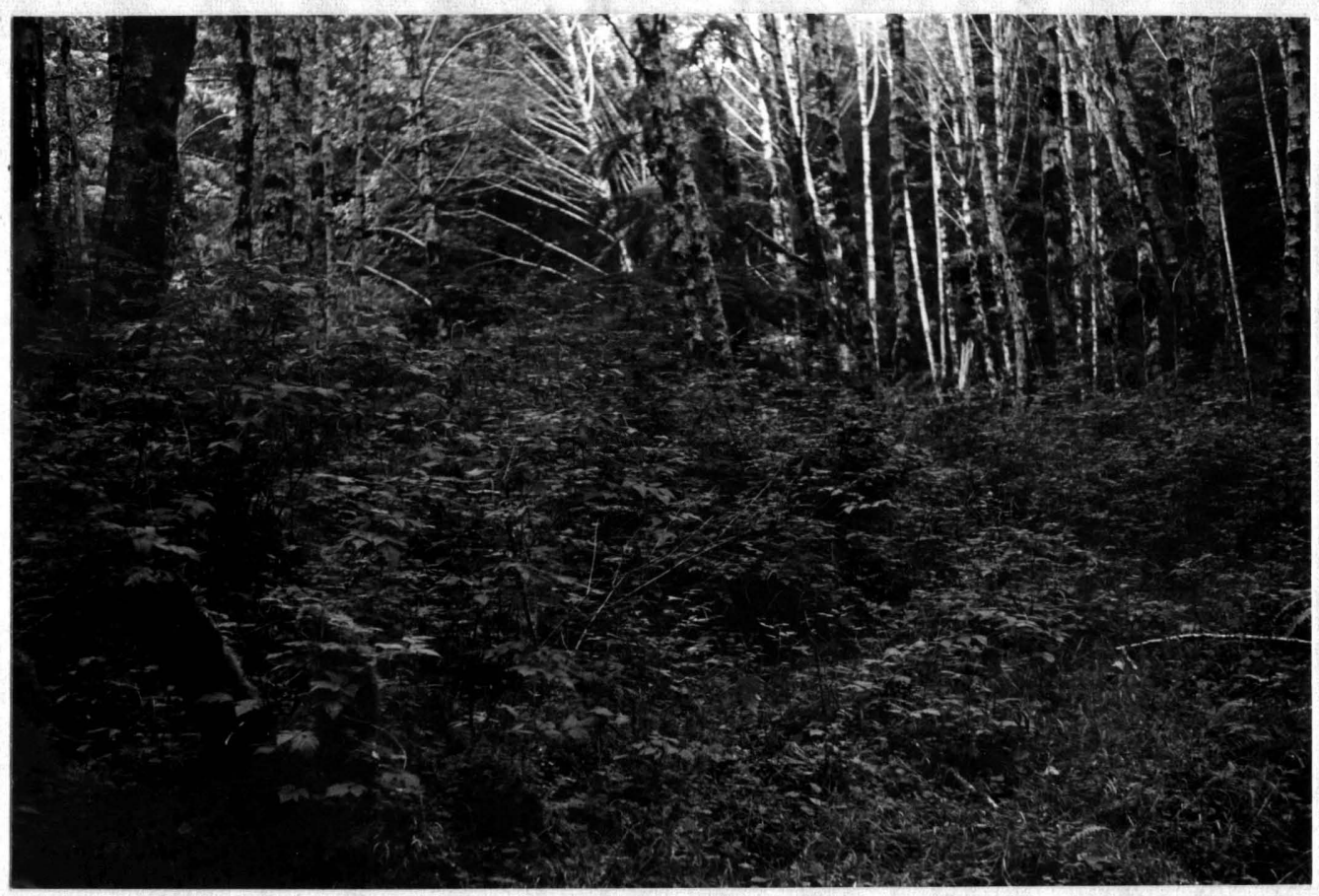

Figure 4. A mixed alder/conifer stand. Openings occur between the salmonberry clones which support other plant species including Douglas-fir. 
After representative sites in clear-cut, mixed alder/Douglas-fir stands, and Douglas-fir forests were selected, the vegetation of each site was divided into tree, shrub, and herbaceous strata. The species were identffied and then frequencies, densities, and abundance were recorded. Particular attention was given to the location of Douglas-fir In relation to salmonberry clones. In each plot the amount of light that each Douglas-fir seedling received was measured on a clear day, June 26 , 1971, by a Sekonic model L-28c photographic 11ghtmeter. The relative stage of maturity of the salmonberry plants in each plot was estimated by their height and an assessment of reproduction was determined by ascertaining the number of newly germinated salmonberry seedlings. Potential interference of salmonberry on Douglas-fir was determined by measuring the height of Douglas-fir in each plot in relation to the density of salmonberry. The vigor of salmonberry and Douglas-fir was determined by noting the color, height, and evidence of chlorosis or necrosis of each plant. :

In order to determine the relationships between salmonberry and Douglas-fir it is necessary to examine each involved abiotic and biotic factor of each spectes' respective environment. Each of the filed measurements of these factors which follow was carried out once a month between May and September, 1971. Soil moisture was determined for each plot in every site: 20 soil sample sites were selected randomly in each plot, samples were collected to a depth of $15 \mathrm{~cm}$, and soil moisture was determined gravimetrically. Soll temperature and ambient air temperature were recorded each sample day every two hours between the hours of 8:00 AM and 4:00 PM. Both temperature measurements were made with a Yellow-Springs 
Tele-thermometer. Soil mineral content was determined on July 10 for three sites using a Soil Tex soll testing kit. Samples tested were collected at $15 \mathrm{~cm}$ depths and mineral determination was made on three randomly chosen plots for each of three sites. The amounts of $\mathrm{NO}_{3}, \mathrm{NH}_{4}, \mathrm{NO}_{2}, \mathrm{P}$, $\mathrm{K}, \mathrm{Ca}, \mathrm{Mg}, \mathrm{Fe}, \mathrm{Al}, \mathrm{CO}_{3}, \mathrm{Mn}, \mathrm{SO}_{4}$, and $\mathrm{Cl}$ were determined and expressed as parts per million (ppm). The pH of each sample was also measured. Light intensities at ground levels were obtained by use of two R401-Mechanical Pyranographs (WeatherMeasure Corp.) which provided a continuous record of the light intensity of sun and sky radiation between the wave lengths of 0.36 and 2.0 microns. One pyranograph was placed beneath a salmonberry canopy while the second machine was placed in an open area to record full light Both machines were started at approximately the same time and run for a minimum of four hours.

To study the possibility of biochemical interference by salmonberry, bioassays were set up as follows: dry, dead salmonberry leaves were collected from the ground, returned to the laboratory, and homogenized in a Waring Blendor. Seven grams of ground leaves and $100 \mathrm{ml}$ of glass distilled water were thoroughly mixed on a shaker for one-half hour. The mixture was allowed to stand for one hour and then the extract was decanted. Twenty seeds of cheatgrass (Bromus tectorum) were arranged in circular fashion on a seedbed of sterilized white mason sand in each of nine $500 \mathrm{ml}$ storage dishes and watered with $10 \mathrm{ml}$ of the extract. Nine controls were watered with glass distilled water. Storage dishes were then sealed with parafilm and placed in cold stratification $\left(5^{\circ} \mathrm{C}\right)$. At the end of 12 hours the storage dishes were removed from cold stratification and placed in a growth chamber at $25^{\circ} \mathrm{C}$ for 43 hours. A second seedbed consisting of filter paper (Whatman \#1) soaked in the extract 
was utilized and set up following the same procedure. A second bioassay seed species, radish (Raphanus sativa) was used following the same procedure but with two modiflcations. Ten seeds were used for each seedbed type and cold stratification was omitted. Percent germination and degree of growth, as estimated by length of the radicle, were determined for both seed types. Seeds of Douglas-fir were used for a third bioassay procedure. The procedure was identical to that of the cheatgrass with two exceptions: ten seeds were used for each seedbed type and the seeds were subjected to cold stratification $\left(5^{\circ} \mathrm{C}\right)$ for 8 ix weeks, and then transferred to a growth chamber $\left(22^{\circ} \mathrm{C}\right)$ for a minimum of seven days. 
RESULTS AND DISCUSSION

The results of this study are divided into two major areas of concentration: determination and description of the fleld association patterns, and analysis of biotic and abiotic factors that could control the observed patterns.

\section{FIELD PATTERNS}

Major species in each plot were identified and total number of stems for each site was recorded (Table I).

In clear-cut areas salmonberry and Douglas-fir can be observed to grow side by side during the very early stages of growth. During these stages the salmonberry are still individual plants and have not yet begun to form clones. As the salmonberry individuals begin to mature, clone formation ensues and as many as twelve stems can be seen coming from the basal portion of the initial stem. After the clone is formed extensive branching of each stem occurs and leaves are profuse only on the periphery of the clone. During the pre-clone stages there is no direct correlation between abundance of salmonberry and Douglas-fir. After clone formation however, the abundance of Douglas-fir is greatly reduced and becomes greater as the height of the salmonberry stand increases. Douglas-fir exists within such a maturing salmonberry stand only when its height exceeds that of the salmonberry or when the salmonberry canopy is discon-. tinuous. In both cases the crown of the Douglas-fir receives direct sunlight. 


\section{TABLE I}

STEM DENSITY OF MAJOR PLANT SPECIES IN

TEN AREAS OF NORTHWEST COASTAL OREGON

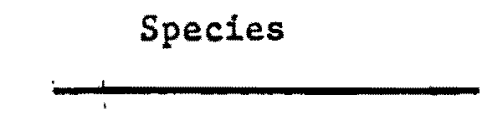

Rubus spectabilis

Pseudotsuga menziesil

Tsuga heterophylla

Picea sitchensis

Acer circinatum

Alnus rubra

Rhamus purshiana

Anaphalis margaritacea

Epilobịum angustifolium

Gaultheria shallon

Polystichum munitum

Pteridium aquilinium

Rubus parviflorous

kubus vitifolium

Sambucus glauca

Taraxacum officinale

Vaccinium ovatum

Vaccinium parvifolium

\begin{tabular}{rrrrrrrrrr}
\multicolumn{10}{c}{ Site } \\
1 & 2 & 3 & 4 & 5 & 6 & 7 & 8 & 9 & 10 \\
\hline 996 & 1078 & 1253 & 1268 & 1471 & 2478 & 224 & 266 & 1023 & 1026 \\
46 & 63 & 95 & 74 & 17 & 24 & 1 & 0 & 4 & 0 \\
79 & 71 & 92 & 70 & 43 & 13 & 1 & 0 & 5 & 3 \\
0 & 1 & 67 & 7 & 8 & 1 & 0 & 0 & 6 & 0 \\
2 & 0 & 2 & 0 & 2 & 0 & 0 & 1 & 16 & 0 \\
5 & 3 & 19 & 6 & 13 & 6 & 22 & 4 & 33 & 2 \\
5 & 0 & 5 & 0 & 6 & 1 & 0 & 0 & 6 & 0 \\
60 & 68 & 18 & 55 & 66 & 30 & 27 & 0 & 0 & 23 \\
46 & 190 & 2 & 106 & 34 & 13 & 21 & 0 & 42 & 22 \\
2 & 0 & 31 & 5 & 1 & 0 & 0 & 0 & 0 & 0 \\
62 & 68 & 107 & 31 & 90 & 42 & 0 & 12 & 30 & 64 \\
87 & 167 & 255 & 68 & 57 & 22 & 121 & 0 & 132 & 60 \\
13 & 0 & 58 & 7 & 1 & 0 & 13 & 0 & 10 & 2 \\
20 & 29 & 33 & 44 & 12 & 14 & 8 & 0 & 0 & 4 \\
1 & 8 & 0 & 1 & 1 & 0 & 0 & 0 & 0 & 1 \\
114 & 67 & 17 & 65 & 11 & 55 & 0 & 0 & 0 & 0 \\
41 & 16 & 11 & 0 & 21 & 0 & 0 & 0 & 0 & 0 \\
13 & 8 & 16 & 17 & 11 & 1 & 2 & 2 & 3 & 3
\end{tabular}

Minor species found in various plots included:

Acer macrophyllum

Adiantum sp.

Athyrium sp.

Cytisus scoparius

Dicentra sp.

Equisetum sp.

Fragaria sp.

Linnaea borealis

Ly copodium sp.

Oplopanox sp.

Osmaronia sp.

Oxalis oregana

Ribes $s p$.

Struthiopteris sp.

Trillium ovatum

Viola sp.

Various members of the Gramineae 
In the mixed alder/conifer stands the association pattern is somewhat different. In all plots observed, no Douglas-fir seedlings were found, elther under a salmonberry canopy or at the periphery of the stand. The Douglas-fir that were observed were either mature trees that helped form the tree canopy of the entire mixed stand or immature trees that helped form the sub-canopy. In these mixed alder/conifer stands the density of both salmonberry and Douglas-fir is greatly reduced as compared to the clear-cut areas (Table II). The average clone contained seven stems, with a maximum number of eleven and these showed reduced branching. The salmonberry canopy is discontinuous and clone density is reduced. Height of the salmonberry clones, on the average, is greater than that found In clear-cut areas. Within a 10m radius of the alder trees, more salmonberry seedlings were observed, whereas outside this radius, root suckers were more prevalent. However, with a reduction in salmonberry density, there is still a noticeable decrease in the density of Douglasfir. Furthermore, in the mixed alder/conifer stands salmonberry grows only up to the drip line of the mature conifers. On one occasion a salmonberry seedling was observed at the base of an old Douglas-fir approximately $0.5 \mathrm{~m}$ from the trunk. When first found the seedling was approximately $5 \mathrm{~cm}$ tall, upright and green with no necrotic or chlorotic spots. When observed elght days later, the seedling was prostrate and severely necrotic. The salmonberry was excluded from beneath old trees of western hemlock and western redcedar along with all other vegetation except several species of moss.

Mature conifer forests were observed and it was found that without disturbance, efther natural or man-made, salmonberry did not occur. 
TABLE II

COMPARISON OF VARIOUS PHYSICAL FACTORS OF TEN SITES IN NORTHWEST COASTAL OREGON

Clear-cut Areas

\begin{tabular}{|c|c|c|c|c|c|c|c|c|}
\hline \multirow[t]{2}{*}{ Site } & \multirow[t]{2}{*}{$\begin{array}{l}\text { Salmonberry } \\
\text { density } 1\end{array}$} & \multirow[t]{2}{*}{$\begin{array}{l}\text { Douglas-fir } \\
\text { density }\end{array}$} & \multicolumn{2}{|c|}{$\begin{array}{l}\text { Salmonberry } \\
\text { abundance }\end{array}$} & \multicolumn{2}{|c|}{$\begin{array}{l}\text { Douglas-fir } \\
\text { abundance }\end{array}$} & \multirow{2}{*}{$\begin{array}{c}\text { Salmonberry } \\
\text { frequency } \\
\text { percent } \\
\text { (p1ots } 1-8)\end{array}$} & \multirow{2}{*}{$\begin{array}{l}\text { Douglas-fir } \\
\text { frequency } \\
\text { percent } \\
\text { (plots 1-8) }\end{array}$} \\
\hline & & & $\begin{array}{l}\text { total } \\
\text { stems }\end{array}$ & $\begin{array}{c}\text { percent } \\
\text { of } \\
\text { plants }\end{array}$ & $\begin{array}{l}\text { total } \\
\text { stems }\end{array}$ & $\begin{array}{c}\text { percent } \\
\text { of } \\
\text { plants }\end{array}$ & & \\
\hline 1 & 12.450 & 0.575 & 996 & 62.09 & 46 & 2.87 & 100 & 50.0 \\
\hline 2 & 13.475 & 0.787 & 1078 & 58.46 & 63 & 3.42 & 100 & 87.5 \\
\hline 3 & 15.662 & 1.186 & 1253 & 60.01 & 95 & 4.54 & 100 & 75.0 \\
\hline 4 & 15.850 & 0.925 & 1268 & 45.11 & 74 & 2.63 & 100 & 87.5 \\
\hline 5 & 18.387 & 0.213 & 1471 & 78.66 & 17 & 0.91 & 100 & 62.5 \\
\hline \multirow[t]{2}{*}{6} & 30.975 & 0.300 & 2478 & 91.74 & 24 & 0.89 & 100 & 25.0 \\
\hline & \multicolumn{8}{|c|}{ Mixed alder/conifer stands } \\
\hline 7 & 5.600 & 0.025 & 224 & 49.78 & 1 & 0.22 & 100 & 25.0 \\
\hline 8 & 6.650 & 0.000 & 266 & 93.33 & 0 & 0.00 & 100 & 0 \\
\hline \multirow[t]{2}{*}{9} & 12.790 & 0.500 & 1023 & 77.73 & 4 & 0.30 & 100 & 25.0 \\
\hline & \multicolumn{8}{|c|}{ Opening between conifer stands } \\
\hline 10 & 17.100 & 0.000 & 1026 & 84.44 & 0 & 0.00 & 100 & 0 \\
\hline
\end{tabular}


TABLE II (continued)

COMPARISON OF VARIOUS PHYSICAL FACTORS OF

TEN SITES IN NORTHWEST COASTAL OREGON

clear-cut Areas

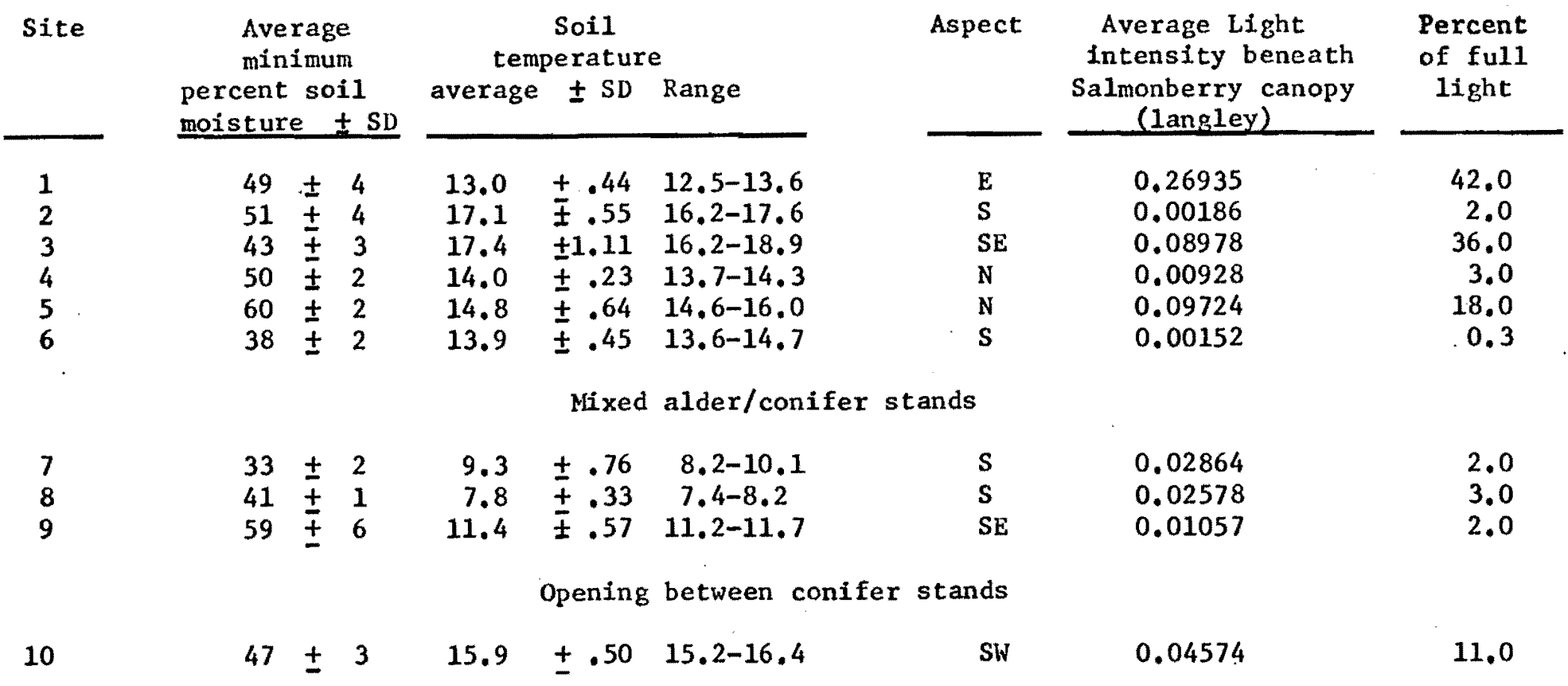


II. ABIOTIC AND BIOTIC FACTORS

The exclusion of Douglas-fir after a salmonberry stand reaches a certain density is particularly indicative of a possible suppression mechanism caused by biotic interference. This interference could be in the farm of competition for soil nutrlents, soil molsture, light, or a subtle biochemical interaction, caused by the addition of metabolic byproducts to the environment. Since soll moisture depletion is a possible cause of suppression, moisture percentages were determined for each plot and the average minimum value for each site recorded (Table II). Annual preclpitation in this region ranges between $200-300 \mathrm{~cm}$ and is supplemented greatly by heavy fog drip (Ruth, 1956). Wilting coefficient for this region ranges between $39.2-40.1$. From the amount of annual precipitation and percent soil moisture for each site it becomes clear that soil molsture is not at a deficit and consequently competition for soil moisture is not probable.

The greatest Douglas-fir density occurs at the highest soil temperature value (Table II). It is possible that in areas with a high density of salmonberry the soil temperature stays below optimum for Douglas-fir growth for most of the day, while in areas with a lesser salmonberry density the Douglas-fir receive much more direct sunlight. In this respect soil temperature could be limiting.

Another possible suppression mechanism is competition for soil nutrients. The results of the analyses of soil nutrients (Table III), compared with data recorded in the 1fterature, are within normal ranges for soils supporting Douglas-fir. Additionally, the results indicate. that nutrient concentration is essentially identical in all plots 
TABLE III

QUANTITATIVE DATA ON SOIL NUTRIENTS IN

TWELVE PLOTS OF NORTHWEST COASTAL OREGON

FIGURES ARE IN PPM

\begin{tabular}{|c|c|c|c|c|c|c|c|c|c|c|c|c|c|c|}
\hline Site & $\mathrm{NO}_{3}$ & $\mathrm{NH}_{4}$ & $\mathrm{NO}_{2}$ & $P$ & $\mathrm{~K}$ & $\mathrm{Ca}$ & $\mathrm{Mg}$ & $\mathrm{Fe}$ & AI & $\mathrm{CO}_{3}{ }^{1}$ & $\mathrm{Mn}$ & $\mathrm{SO}_{4}$ & $\mathrm{CI}$ & $\mathrm{pH}$ \\
\hline 1 & $\begin{array}{r}10 \\
2 \\
5\end{array}$ & $\begin{array}{r}10 \\
2 \\
10\end{array}$ & $\begin{array}{l}1 \\
1 \\
1\end{array}$ & $\begin{array}{l}.5 \\
.5 \\
.5\end{array}$ & $\begin{array}{r}5 \\
10 \\
10\end{array}$ & $\begin{array}{l}20 \\
20 \\
20\end{array}$ & $\begin{array}{l}2 \\
2 \\
2\end{array}$ & $\begin{array}{l}2 \\
2 \\
2\end{array}$ & $\begin{array}{l}2 \\
3 \\
2\end{array}$ & $\begin{array}{l}- \\
-\end{array}$ & $\begin{array}{l}1 \\
1 \\
1\end{array}$ & $\begin{array}{l}20 \\
20 \\
20\end{array}$ & $\begin{array}{l}5 \\
5 \\
5\end{array}$ & \\
\hline 5 & $\begin{array}{l}5 \\
2 \\
2\end{array}$ & $\begin{array}{l}2 \\
2 \\
2\end{array}$ & $\begin{array}{l}1 \\
1 \\
1\end{array}$ & $\begin{array}{l}.5 \\
.5 \\
.5\end{array}$ & $\begin{array}{l}5 \\
5 \\
5\end{array}$ & $\begin{array}{l}20 \\
20 \\
20\end{array}$ & $\begin{array}{l}2 \\
2 \\
2\end{array}$ & $\begin{array}{l}2 \\
2 \\
2\end{array}$ & $\begin{array}{l}3 \\
3 \\
3\end{array}$ & $\begin{array}{l}+ \\
-\end{array}$ & $\begin{array}{l}1 \\
1 \\
1\end{array}$ & $\begin{array}{l}20 \\
20 \\
20\end{array}$ & $\begin{array}{l}5 \\
5 \\
5\end{array}$ & \\
\hline 3 & $\begin{array}{l}2 \\
2 \\
2\end{array}$ & $\begin{array}{l}2 \\
2 \\
2\end{array}$ & $\begin{array}{l}1 \\
1 \\
1\end{array}$ & $\begin{array}{r}.5 \\
.5 \\
.5\end{array}$ & $\begin{array}{l}5 \\
5 \\
5\end{array}$ & $\begin{array}{l}20 \\
20 \\
20\end{array}$ & $\begin{array}{l}2 \\
2 \\
2\end{array}$ & $\begin{array}{l}2 \\
2 \\
2\end{array}$ & $\begin{array}{l}3 \\
3 \\
3\end{array}$ & $\overline{+}$ & $\begin{array}{l}1 \\
1 \\
1\end{array}$ & $\begin{array}{l}20 \\
20 \\
20\end{array}$ & $\begin{array}{l}5 \\
5 \\
5\end{array}$ & $\begin{array}{l}5.0 \\
4.5 \\
4.0\end{array}$ \\
\hline 6 & $\begin{array}{r}10 \\
10 \\
5\end{array}$ & $\begin{array}{r}25 \\
2 \\
10\end{array}$ & $\begin{array}{l}1 \\
1 \\
1\end{array}$ & $\begin{array}{l}.5 \\
.5 \\
.5\end{array}$ & $\begin{array}{l}10 \\
10 \\
10\end{array}$ & $\begin{array}{r}150 \\
20 \\
20\end{array}$ & $\begin{array}{l}2 \\
4 \\
2\end{array}$ & $\begin{array}{l}2 \\
2 \\
2\end{array}$ & $\begin{array}{l}3 \\
3 \\
3\end{array}$ & $\begin{array}{l}- \\
+ \\
+\end{array}$ & $\begin{array}{l}1 \\
1 \\
1\end{array}$ & $\begin{array}{l}20 \\
20 \\
20\end{array}$ & $\begin{array}{l}5 \\
5 \\
5\end{array}$ & \\
\hline
\end{tabular}

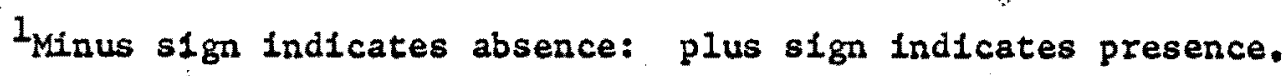


examined which suggests that competition for nutrients is not an operative mechanism in this study. Furthermore, nutrient deficiency symptoms were not observed in any site. However detailed soil nutrient analysis is necessary to eliminate the possibility of competition for nutrients. Light is known to limit plant distribution and growth at certain times of the year or during certain stages of development, either by an over abundance or by a deficiency. As a seeding, Douglas-fir is considered to be fairly intolerant of shade and suppression by competition for light has been alluded to by various workers (Isaac, 1938; Morris, 1958; Ruth, 1967), Other workers however, point out the fact that Douglas-fir seedlings once germinated, thrive in a small amount of shade caused by inanimate objects rather than direct sunlight (Minore, 1971). Because of this fact, radiant energy was measured to ascertain the effects of a reduced amount of light upon the establishment of Douglas-fir. I found no obvious pattern involving light intensity in clear-cut areas (Table II). In the mixed alder/conifer stands, however, a positive correlation exists between salmonberry density and light intensity. With a more dense canopy, such as that produced by a continuous canopy of alder trees, the amount of radiation entering the sub-canopy is greatly reduced due to reflection and absorption by the canopy. It was found that density of salmonberry is less under alder/conffer canopies than in clear-cut areas and this reduction in density appears to be correlated with the reduction in the intensity of light. In both types of areas, clear-cuts and mixed alder/conifer stands, light reduction in salmonberry stands could be sufficient to be detrimental to Douglas-fir establishment and growth. However, further experimentation would need to be performed to determine exact interactions. 
The final factor to be considered is that of a possible biochemical interference between the two plants. The results of my bioassays are recorded in Tables IV, V, and VI. Average radicle length of unhibited radish seeds was $25 \mathrm{~mm}$ after 48 hours. Radicle length of cheatgrass at the end of 72 hours was $22 \mathrm{~mm}$. Average radicle length of Douglas-fir seeds at the end of four weeks was $29 \mathrm{~mm}$. When seeds of radish (Table IV) were treated with the leaf extract there was a significant reduction in both germination and growth. Radicle length was reduced to an average of 40 percent of control on the sand seedbed while germination was reduced to 33 percent of control. On filter paper seedbeds, radicle length was reduced to 49 percent of control while germination was not affected. A $2 \times 2$ factorial analysis showed that both germination and radicle length was significantly reduced (at the $5 \%$ level) when the sand seedbed was used. On filter paper seedbeds only radicle length was significantly reduced. From these results it appears that salmonberry leaves contain a phytotoxin that is effective to a greater degree when combined with soil particles.

- Results in Table $V$ indicate an increased germination and growth in the treatments as compared to the controls. Radical length was increased to as much as 119 percent of control on a sand seedbed and 138 percent of control on a filter paper seedbed. A 2 X 2 factorial analysis was performed which showed no significant difference. These results are contradictory to already published results (del Moral and Cates, 1971).

Inspection of Table VI shows a reduction In radicle length for Douglas-fir seeds that is slgniflcant at the $1 \%$ level. Germination and growth on sand seedbeds was erratic while there was no germination on filter paper seedbeds even after six weeks in the growth chamber. A 
possible explanation for the failure on filter paper could be the lack of moisture retention by the paper over a six week period, Radicle length was reduced to 57 percent of control on the sand seedbed while germination was reduced to 50 percent of control.

The results gathered from these bioassays indicate that salmonberry contains a water-soluble growth inhibitor that is potentially allelopathic. The fact that senescent leaves were utilized to make the extract Indicates that leaf litter in the field is one source of phytotoxins. 
TABLE IV

RADICLE LENGTH AND GERMINATION RESULTS FROM BIOASSAYS UTILIZING SEEDS OF RADISH. TREATNENT CONSITS OF APPLICATION OF LEAF EXTRACT FROM SALMONBERRY. AVERAGES FOR GERMINATION AND RADICLE LENGTH ARE COMPUTED ON THREE TRIALS. TRIALS ONE AND

THREE CONSISTED OF SIX REPLICATIONS EACH CONTAINING TEN SEEDS PER REPLICATION FOR TREATMENT AND CONTROL ON BOTH SAND AND FILTER PAPER SEEDBED; TRIAL TWO CONTAINED NINE REPLICATIONS (SEE STATISTICAL ANALYSIS IN APPENDIX).

Sand Seedbed

\begin{tabular}{|c|c|c|c|c|c|c|c|c|c|}
\hline \multirow[t]{3}{*}{ Trial } & \multicolumn{3}{|c|}{ Control } & \multicolumn{5}{|c|}{ Treatment } & \multirow[b]{3}{*}{$\begin{array}{c}\% \text { of } \\
\text { control }\end{array}$} \\
\hline & \multirow{2}{*}{$\begin{array}{l}\text { Average } \\
\text { germin- } \\
\text { ation }\end{array}$} & & \multirow{2}{*}{$\begin{array}{l}\text { Average } \\
\text { germin- } \\
\text { ation }\end{array}$} & \multirow[b]{2}{*}{$\begin{array}{l}\% \text { of } \\
\text { control }\end{array}$} & \multirow{2}{*}{\multicolumn{3}{|c|}{ Average }} & \\
\hline & & $\begin{array}{l}\text { Average } \\
\text { length }(\mathrm{mm})\end{array}$ & $\pm S D$ & & & & & & \\
\hline$\# 1$ & 9 & 30.6 & +0.27 & 7 & $(70) \star \star \star$ & 16.1 & +0.20 & $\star$ & (54) \\
\hline$\$ 2$ & 8 & 26.9 & \pm 4.22 & 6 & $(75) *$ & 9.0 & \pm 0.29 & $* *$ & (33) \\
\hline$\# 3$ & 9 & 21.3 & \pm 2.72 & 5 & (56) $* *$ & 7.2 & \pm 0.16 & $* *$ & (34) \\
\hline & & & & ilter pal & r seedbed & & & & \\
\hline$\# 1$ & ${ }_{10}^{7}$ & $\begin{array}{l}19.5 \\
26.8\end{array}$ & $\begin{array}{l} \pm 4.10 \\
\pm 2.76\end{array}$ & 10 & $\left(\begin{array}{l}14 \\
100)\end{array}\right.$ & $\begin{array}{l}20.8 \\
12.8\end{array}$ & $+5: 74$ & & $(186)$ \\
\hline 13 & 9 & 25.4 & \pm 0.51 & 9 & (100) & 12.7 & \pm 1.15 & & (50) \\
\hline
\end{tabular}

*Difference significant at the $5 \%$ level by a $2 \times 2$ factorial analysis.

**Difference significant at the $1 \%$ level by a $2 \times 2$ factorial analysis. 
TABLE V

RADICLE LENGTH AND GERMINATION RESULTS FROM BIOASSAYS UTILIZING SEEDS OF CHEATGRASS. TREATMENT CONSISTS OF APPLICATION OF LEAF EXTRACT FROM SALMONBERRY. AVERAGES FOR GERMINATION AND RADICLE LENGTH ARE COMPUTED ON THREE TRIALS, EACH TRIAL CONSISTED OF THREE REPLICATIONS EACH CONTAINING TWENTY SEEDS PER REPLICATION FOR TREATMENT AND CONTROL ON BOTH SAND AND FILTER PAPER SEEDBEDS (SEE STATISTICAL ANALYSIS IN APPENDIX).

Sand Seedbed

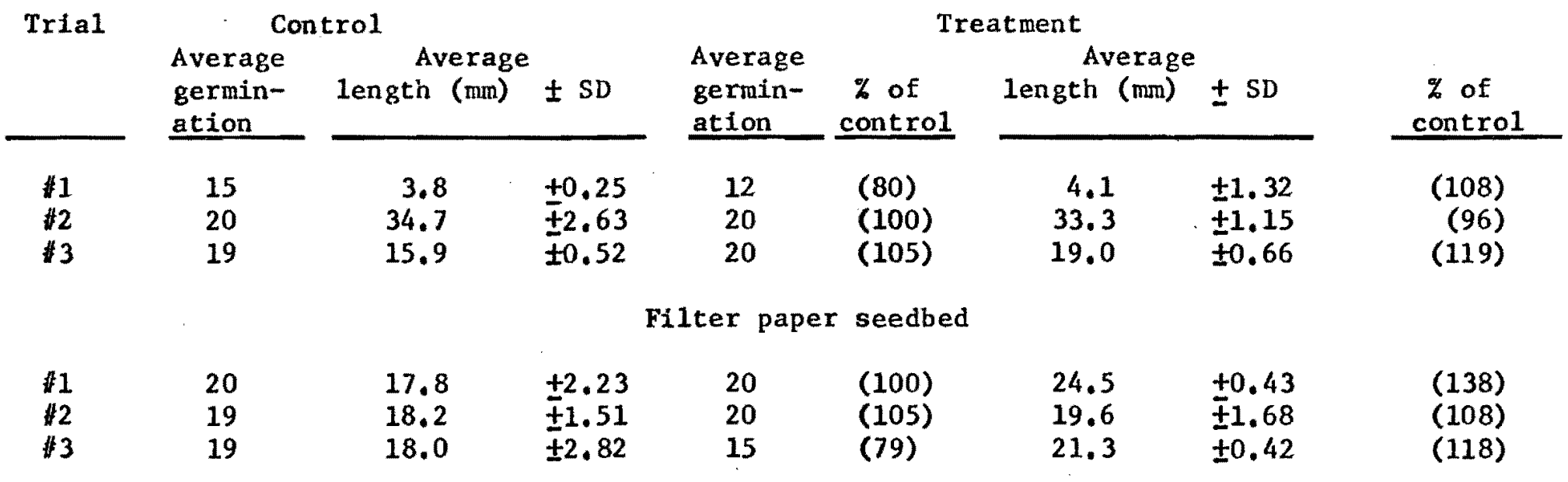


TABLE VI

RADICLE LENGTH AND GERMINATION RESULTS FROM BIOASSAYS UTILIZING SEEDS OF DOUGLASFIR. TREATMENT CONSISTS OF APPLICATION OF LEAF EXTRACT FROM SALMONBERRY. AVERAGES FOR GERMINATION AND RADICLE LENGTH ARE COMPUTED FROM ONE TRIAL CONSISTING OF TWELVE REPLICATIONS AND TWELVE CONTROLS. EACH REPLICATION CONTAINED TEN SEEDS.

Sand Seedbed

\begin{tabular}{|c|c|c|c|c|c|c|c|c|}
\hline \multirow[t]{2}{*}{ Trial } & \multicolumn{3}{|c|}{ Control } & \multicolumn{4}{|c|}{ Treatment } & \multirow[b]{2}{*}{$\begin{array}{c}\% \text { of } \\
\text { control }\end{array}$} \\
\hline & $\begin{array}{l}\text { Average } \\
\text { germin- } \\
\text { atton }\end{array}$ & $\begin{array}{l}\text { Average } \\
\text { length (mm) }\end{array}$ & $\pm \mathrm{SD}$ & $\begin{array}{l}\text { Average } \\
\text { germin- } \\
\text { ation }\end{array}$ & $\begin{array}{l}\% \text { of } \\
\text { control }\end{array}$ & $\begin{array}{l}\text { Average } \\
\text { length (mm) }\end{array}$ & $\pm S D$ & \\
\hline$\# 1$ & 6 & 28.8 & \pm 6.56 & 3 & (50) & 16.3 & $\pm 6.05 * *$ & (57) \\
\hline
\end{tabular}

**Difference significant at the $1 \%$ level by a test. 


\section{CONCLUSIONS}

Within any given plant community, competition can occur between members of the same species or between members of different species whenever an essential requirement is insufficient to supply the needs of the involved organisms. In the Pacific Northwest coastal areas weather patterns are quite variable and the environment is extremely diverse and complex. With a readily available supply of soil water the possibility of competition for soil moisture is slight. All species in an association would have sufficient moisture available to insure growth. In all areas examined for soil nutrients, concentrations were simllar. There was no correlation between changes in concentration of nutrients from site to site and the changes in vegetational composition. If particular nutrients had been absent, nutrient deficiency symptoms would have appeared in the vegetation of that area. In all plots examined nutrient deficiency symptoms were not observed. Thus, the possibility of nutrients being limited is slight. Observed field patterns in this study strongly indicate that shading by salmonberry could be suppressing Douglas-fir. However, there appears to be no discernible pattern between the availability of light and the density of Douglas-fir. As suggested by the definition, competition must reduce the level of some necessary factor to the detriment of some other plant in the same habitat and it is obvious that light is not independently the causative factor in the reduction of Douglas-fir density in these areas. Furthermore, recorded results from other Investigators 
indicate that in all but site six there is sufficient light for Douglasfir survival (Bates, 1925, 1928).

The results obtained from my bioassay experiments indicate that salmonberry is phytoxic. Furthermore, since a water extract of the dead leaves yielded the toxicity, this indicates that the chemicals involved are water soluble and that the litter is one source of them. Allelopathic expression is ordinarily considered to be synergistic with certain physical factors of the environment. I hypothesize that immature salmonberry plants do not excrete sufficient quantities of the toxins to be detrimental. At the same time the immaturity of the salmonberry causes less shade at ground level. The correlation between low toxicity and relatively high light intensities allows the initiation of young Douglasfir seedlings. However, as the salmonberry matures the canopy closes thus causing more shade while at the same time there is a measureable increase in toxin excretion. With this increase in toxicity coupled with other environmental stresses (decreased availability of light) there occurs the subsequent reduction of Douglas-fir.

The observation that mature conffer forests support very little understory vegetation suggests a reversal of the procedure stated above. In the young seedling stage salmonberry may quite effectively reduce Douglas-fir density, but once a mature stand of Douglas-fir is established, it is possible that there is a reciprocal effect. Thus, various interference mechanisms in a mature conifer forest explain some of the subtle changes of understory vegetational patterns. 


\section{REFERENCES}

Bates, C. G. 1925. "The relative light requirements of some coniferous seedlings." J. For. 23:869-879.

Bates, C. G., and Jacob Roeser, Jr, 1928, "Light intensities required for growth of coniferous seedlings." Amer. J. Bot. 15:185-194.

Debe1I, Dean S. 1970. "Phytotoxic effects of Cherrybark Oak." Forest Sci. $17: 180-185$.

Del Moral, R, and R. C. Cates, 1971. "Allelopathic potential of the dominant vegetation of western Washington." Ecol.52:1030-1037.

Doby, G. 1965. Plant Biochemistry. 786 pp. Wiley (interscience), New York.

Garb, S. 1961. "Differential growth inhibitors produced by plants." Botan. Rev. 27,422-443.

Gratkowsk1, H. 1961. "Brush problems in southwestern Oregon." USDA Forest Serv. Pacific Northwest Forest and Range Exp. Sta. $5 \overline{4 \mathrm{pp}}$. illus. (Processed).

Isaac, L. A. 1938. "Factors affecting establishment of Douglas-fir seedlings." U.S. Dept. Agri. Cir. 486, $45 \mathrm{pp}$.

Krygier, James T., and Robert H. Ruth. 1961. "Effect of herbicides on salmonberry and on Sitka spruce and western hemlock seedlings." Weeds $9: 416-422$.

Minore, Don. 1971. "Shade benefits Douglas-fir in southwestern Oregon cutover area." Tree Planters' Notes. 22:

Moravete, F. L. 1959. "Forest statistics for southwest Oregon Unit." U. S. Forest Serv. Pac. NW. Forest and Range Exp. Sta. Forest Survey Rpt, 104,36 pp., ililud, (Processed).

Muller, C. H. 1966. "The role of chemical inhibition (allelopathy) in vegetational composition." Bull. Torrey Bot. Club, 93:332-351.

Muller, C. H. 1969. "Allelopathy as a factor in ecological process." Vegetation. 18:348-357.

Peck, Morton E. 1961. A Manual of the Higher Plants of Oregon. Ed. 2, 936 pP., illus. Portland, Oregon. Binfords and Mort. 
Ruth, Robert N. 1956. "Plantation survival and growth in two brushthreat areas in coastal Oregon." USDA Forest Serv. Pacific Northwest Forest and Range Exp. Sta. Res. Paper, 17,14 pp., illus.

- 1967. "Differential effect of solar radiation on seedling estabiishment under a forest stand." Unpub. doctoral thesis at Oregon State Univ., Corvallis, $165 \mathrm{pp}$.

Sokol, Robert, R, and F. James Rohlf, 1969, Blometry. 776 pp. W. H. Freeman and Co. San Francisco.

Whittaker, R. H. 1970. "The biochemical ecology of higher plants."

In Chemical Ecology, E. Sondheimer and J. B. Simeone (Eds.). Academic Press, New York. 


\section{APPENDIX}

TWO-WAY ANALYSIS OF VARIANCE WITH REPIICATION (Tables 1-6)

Number of germinated seeds of Raphanus sativa and length of radical of gerninated seeds when treated with a water extract of salmonberry leaves (treatment) or glass distilled water (control). Six replicates each containing ten seeds per combination of substrate and treatment with ", the exception of trial number two which had nine replicates. Total of four combinations. This is a model I ANOVA.

ANOVA Table 1

COMPUTED VALUES REFER TO RADICLE LENGTH OF R. SATIVA

IN TRIAL NUMBER ONE LOCATED IN TABLE IV, PAGE 20.

\begin{tabular}{|c|c|c|c|c|}
\hline Source of variation. & df & SS & MS & Es \\
\hline $\begin{array}{l}\text { Subgroups (treatment SS) } \\
\text { A (columns; control- } \\
\text { treatment con- } \\
\text { trast) }\end{array}$ & $\begin{array}{l}3 \\
1\end{array}$ & $\begin{array}{l}35.240 \\
21.786\end{array}$ & $\begin{array}{l}11.747 \\
21.786\end{array}$ & $8.039 *$ \\
\hline $\begin{array}{l}\text { B (rows; substrate) } \\
\text { A X B (interaction) } \\
\text { Within subgroups (error) } \\
\text { Tota1 SS }\end{array}$ & $\begin{array}{r}1 \\
1 \\
20 \\
23\end{array}$ & $\begin{array}{r}13.113 \\
0.341 \\
54.209 \\
89.449\end{array}$ & $\begin{array}{r}13.113 \\
0.341 \\
2.710\end{array}$ & $\begin{array}{l}4.838 \\
0.125\end{array}$ \\
\hline
\end{tabular}


COMPUTED VALUES REFER TO NUMBER OF GERMINATED SEEDS OF R. SATIVA IN TRIAL NUMBER ONE LOCATED IN TABLE IV, $\frac{\text { PG. } 20 .}{\text { PG. }}$

\begin{tabular}{|c|c|c|c|c|c|}
\hline Source of variance & $d f$ & SS & $\mathrm{MS}$ & Fs & \\
\hline $\begin{array}{c}\text { Subgroups (treatment SS) } \\
\text { A (columns; control- } \\
\text { treatment con- } \\
\text { trast) }\end{array}$ & $\begin{array}{l}3 \\
1\end{array}$ & $\begin{array}{r}21.877 \\
8.642\end{array}$ & $\begin{array}{l}7.259 \\
8.642\end{array}$ & 45.010 & ** \\
\hline $\begin{array}{l}\text { B (rows; substrate) } \\
\text { A X B (interaction) } \\
\text { Within subgroups (error) } \\
\text { Total'ss }\end{array}$ & $\begin{array}{r}1 \\
1 \\
20 \\
23\end{array}$ & $\begin{array}{r}9.243 \\
3.992 \\
3.834 \\
25.711\end{array}$ & $\begin{array}{l}9.243 \\
3.992 \\
0.192\end{array}$ & $\begin{array}{l}48.140 \\
20.791\end{array}$ & $\begin{array}{l}* * \\
* *\end{array}$ \\
\hline . & & & & $\begin{array}{r}\mathrm{F} .05 \\
* * \mathrm{~F} .01\end{array}$ & $\begin{array}{l}(1,20)=5.87 \\
(1,20)=9.94\end{array}$ \\
\hline
\end{tabular}

ANOVA Table 3

COMPUTED VALUES REFER TO RADICLE LENGTH OR R. SATIVA

IN TRIAL NUMBER TWO LOCATED IN TABLE IV PG, 20 .

\begin{tabular}{|c|c|c|c|c|}
\hline Source of variance & $d f$ & SS & $M S$ & Fs \\
\hline $\begin{array}{c}\text { Subgroups (treatment SS) } \\
\text { A (columns; control- } \\
\text { treatment con- } \\
\text { trast) }\end{array}$ & $\begin{array}{l}3 \\
1\end{array}$ & $\begin{array}{l}31.033 \\
29.597\end{array}$ & $\begin{array}{l}10.344 \\
29.597\end{array}$ & 45.394 \\
\hline $\begin{array}{l}\text { B (rows; substrate) } \\
\text { A X B (interaction) } \\
\text { Within subgroups (error) } \\
\text { Total ss }\end{array}$ & $\begin{array}{r}1 \\
1 \\
32 \\
35\end{array}$ & $\begin{array}{r}0.571 \\
0.865 \\
20.872 \\
51.905\end{array}$ & $\begin{array}{l}0.571 \\
0.865 \\
0.652\end{array}$ & $\begin{array}{l}0.876 \\
1.326\end{array}$ \\
\hline
\end{tabular}

$$
\begin{gathered}
F \quad 05(1,32)= \\
5.57-5.29 \\
* * F \quad 01(1,32)= \\
9.18-8.49
\end{gathered}
$$


ANOVA Table 4

COMPUTED VALUES REFER TO NUMBER OF GERMINATED SEEDS

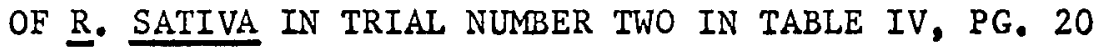

\begin{tabular}{|c|c|c|c|c|c|}
\hline Source of variance & $\mathrm{df}$ & SS & MS & Fs & \\
\hline $\begin{array}{l}\text { Subgroups (treatment SS) } \\
\text { A (columns; control- } \\
\text { treatment con- } \\
\text { trast) }\end{array}$ & $\begin{array}{l}3 \\
1\end{array}$ & $\begin{array}{l}3.278 \\
0.451\end{array}$ & $\begin{array}{l}1.093 \\
0.451\end{array}$ & 7.046 & $\star$ \\
\hline $\begin{array}{l}\text { 'B (rows; substrate) } \\
\text { A X B (interaction) } \\
\text { Within subgroups (error) } \\
\text { Total sS }\end{array}$ & $\begin{array}{r}1 \\
1 \\
32 \\
35\end{array}$ & $\begin{array}{l}2.420 \\
0.407 \\
2.043 \\
5.321\end{array}$ & $\begin{array}{l}2.420 \\
0.407 \\
0.064\end{array}$ & $\begin{array}{r}37.812 \\
6.359\end{array}$ & $* *$ \\
\hline & & & & \multicolumn{2}{|c|}{$\begin{array}{r}* F \quad 05(1,32)= \\
5.57-5.29\end{array}$} \\
\hline : : & & & & $\begin{array}{r}* * F .01 \\
9\end{array}$ & $\begin{array}{l}(1,32)= \\
18-8.49\end{array}$ \\
\hline
\end{tabular}

ANOVA table 5

COMPUTED VALUES REFER TO RADICLE LENGTH OF R. SATIVA

IN TRIAL NUMBER THREE LOCATED IN TABLE IV, $\bar{P} G, \overline{20}$.

\begin{tabular}{|c|c|c|c|c|}
\hline Source of variance & $\mathrm{df}$ & SS & MS & Fs \\
\hline $\begin{array}{l}\text { Subgroups (treatment SS) } \\
\text { A (colums; control- } \\
\text { treatment con- } \\
\text { trast) }\end{array}$ & $\begin{array}{l}3 \\
1\end{array}$ & $\begin{array}{l}17.857 \\
15.637\end{array}$ & $\begin{array}{r}5.952 \\
15.637\end{array}$ & 36.280 \\
\hline $\begin{array}{l}\text { B (rows; substrate) } \\
\text { A X B (interaction) } \\
\text { Within subgroups (error) } \\
\text { Total ss }\end{array}$ & $\begin{array}{r}1 \\
1 \\
20 \\
23\end{array}$ & $\begin{array}{r}1.710 \\
0.510 \\
8.629 \\
26.486\end{array}$ & $\begin{array}{l}1.710 \\
0.510 \\
0.431\end{array}$ & $\begin{array}{l}3.967 \\
1.183\end{array}$ \\
\hline
\end{tabular}

$$
\begin{aligned}
& { }_{* * \mathrm{~F}}^{* \mathrm{~F}} .05(1,20)=5.87 \\
& .01(1,20)=9.94
\end{aligned}
$$


ANOVA Table 6

COMPUTED VALUES REFER TO NUMBER OF GERMINATED SEEDS

OF $\underline{R}$. SATIVA IN TRIAL NUMBER THREE IN TABLE IV, PG. 20

\begin{tabular}{|c|c|c|c|c|c|}
\hline Source of variance & df & SS & $M S$ & Fs & \\
\hline $\begin{array}{c}\text { Subgroups (treatment SS) } \\
\text { A (colums; control- } \\
\text { treatment con- } \\
\text { trast) }\end{array}$ & $\begin{array}{l}3 \\
1\end{array}$ & $\begin{array}{l}2.855 \\
1.207\end{array}$ & $\begin{array}{l}0.952 \\
1.207\end{array}$ & 20.457 & $* *$ \\
\hline $\begin{array}{l}\text { B (rows; substrate) } \\
\text { A X B (interaction) } \\
\text { Within subgroups (error) } \\
\text { Total SS }\end{array}$ & $\begin{array}{r}1 \\
1 \\
20 \\
23\end{array}$ & $\begin{array}{l}1.057 \\
0.591 \\
1.181 \\
4.036\end{array}$ & $\begin{array}{l}1.057 \\
0.591 \\
0.059\end{array}$ & $\begin{array}{l}17.915 \\
10.016\end{array}$ & $\begin{array}{l}* * \\
\dot{*}\end{array}$ \\
\hline & & & & \multicolumn{2}{|c|}{ 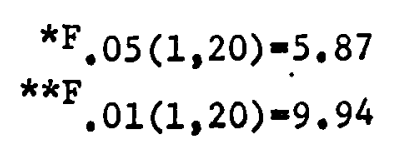 } \\
\hline
\end{tabular}


TWO-WAY ANALYSIS OF VARIANCE WITH REPLICATION (Tables 7-12)

Number of germinated seeds of Bromus tectorum and length of radicle of germinated seeds when treated with a water extract of salmonberry leaves (treatment) or glass distilled water (control). Three replicates, each containing twenty seeds per combination of substrate and treatment. Total of four considerations. This is a model I ANOVA.

\section{ANOVA Table 7}

COMPUTED VALUES REFER TO RADICLE LENGTH OF B. TECTORUM IN TRIAL NUMBER ONE LOCATED IN TABLE $V, P G .21$.

\begin{tabular}{|c|c|c|c|c|}
\hline Source of variance & $\mathrm{df}$ & SS & MS & Fs \\
\hline $\begin{array}{l}\text { Subgroups (treatment SS ) } \\
\text { A (columns; control- } \\
\text { treatment con- } \\
\text { trast) }\end{array}$ & $\begin{array}{l}3 \\
1\end{array}$ & $\begin{array}{r}20.965 \\
0.485\end{array}$ & $\begin{array}{l}6.988 \\
0.485\end{array}$ & 7.348 \\
\hline $\begin{array}{l}\text { B (rows: substrate) } \\
\text { A X B (interaction) } \\
\text { Within subgroups (error) } \\
\text { Total ss }\end{array}$ & $\begin{array}{r}1 \\
1 \\
8 \\
11\end{array}$ & $\begin{array}{r}20.027 \\
0.453 \\
0.526 \\
21.491\end{array}$ & $\begin{array}{r}20.027 \\
0.453 \\
0.066\end{array}$ & $\begin{array}{r}303.439 \\
6.863\end{array}$ \\
\hline
\end{tabular}

ANOVA Table 8

COMPUTED VALUES REFER TO NUMBER OF GERMINATED SEEDS OF B. TECTORUM IN TRIAL NUMBER ONE LOCATED IN TABLE V. PG. 21 .

\begin{tabular}{|c|c|c|c|c|}
\hline Source of variance & $d f$ & SS & MS & Es \\
\hline $\begin{array}{c}\text { Subgroups (treatment SS) } \\
\text { A (columns; control- } \\
\text { treatment con- } \\
\text { trast) }\end{array}$ & $\begin{array}{l}3 \\
1\end{array}$ & $\begin{array}{l}2.203 \\
0.097\end{array}$ & $\begin{array}{l}0.734 \\
0.097\end{array}$ & 0.707 \\
\hline $\begin{array}{l}\text { B (rows: substrate) } \\
\text { A X B (interaction) } \\
\text { W1thin subgroups (error) } \\
\text { Total ss }\end{array}$ & $\begin{array}{r}1 \\
1 \\
8 \\
11\end{array}$ & $\begin{array}{l}1.964 \\
0.141 \\
1.098 \\
3.300\end{array}$ & $\begin{array}{l}1.964 \\
0.141 \\
0.137\end{array}$ & $\begin{array}{r}14.333 \\
1.029\end{array}$ \\
\hline
\end{tabular}

$$
\begin{array}{r}
* F \\
* * F \quad .05(1,8)=7.57 \\
.01(1,8)=14.7
\end{array}
$$


ANOVA Table 9

COMPUTED VALUES REFER TO RADICLE LENGTH OF B. TECTORUM

IN TRIAL NUMBER TWO LOCATED IN TABLE V, PG. 21.

\begin{tabular}{|c|c|c|c|c|}
\hline Source of variance & df & SS & $\mathrm{MS}$ & Fs \\
\hline $\begin{array}{l}\text { Subgroups (treatment SS) } \\
\text { A (columns; control- } \\
\text { treatment con- } \\
\text { trast) }\end{array}$ & $\begin{array}{l}3 \\
1\end{array}$ & $\begin{array}{l}0.333 \\
0.274\end{array}$ & $\begin{array}{l}0.111 \\
0.274\end{array}$ & $9.785 *$ \\
\hline $\begin{array}{l}\text { B (rows; substrate) } \\
\text { A X B (interaction) } \\
\text { Within subgroups (error) } \\
\text { Total SS }\end{array}$ & $\begin{array}{r}1 \\
1 \\
8 \\
11\end{array}$ & $\begin{array}{l}0.047 \\
0.012 \\
0.220 \\
0.553\end{array}$ & $\begin{array}{l}0.047 \\
0.012 \\
0.028\end{array}$ & $\begin{array}{l}1.678 \\
0.428\end{array}$ \\
\hline . & & & & $\begin{array}{l}* \mathrm{~F} \\
.05(1,8)=7.57 \\
.01(1,8)=14.7\end{array}$ \\
\hline
\end{tabular}

ANOVA Table 10

COMPUTED VALUES REFER TO NUMBER OF GERMINATED SEEDS

OF $\underline{B}$. TECTORUM IN TRIAL NUMBER TWO LOCATED IN TABLE

V. PG. 21 .

\begin{tabular}{|c|c|c|c|c|}
\hline Source of variance & df & SS & $\mathrm{MS}$ & Fs \\
\hline $\begin{array}{l}\text { Subgroups (treatment SS) } \\
\text { A (columns; control- } \\
\text { treatment con- } \\
\text { trast) }\end{array}$ & $\begin{array}{l}3 \\
1\end{array}$ & $\begin{array}{l}0.047 \\
0.039\end{array}$ & $\begin{array}{l}0.016 \\
0.039\end{array}$ & 6.500 \\
\hline $\begin{array}{l}\text { B (rows; substrate) } \\
\text { A X B (interaction) } \\
\text { Within subgroups (error) } \\
\text { Total SS }\end{array}$ & $\begin{array}{r}1 \\
1 \\
8 \\
11\end{array}$ & $\begin{array}{l}0.004 \\
0.004 \\
0.046 \\
0.093\end{array}$ & $\begin{array}{l}0.004 \\
0.004 \\
0.006\end{array}$ & $\begin{array}{l}0.667 \\
0.667\end{array}$ \\
\hline
\end{tabular}

$$
\begin{array}{r}
* F .05(1,8)=7.57 \\
* * F \quad .01(1,8)=14.7
\end{array}
$$


ANOVA Table 11

COMPUTED VALUES REFER TO RADICLE LENGTH OF B. TECTORUM IN TRIAL NUMBER THREE LOCATED IN TABLE V, P $\bar{G}, \overline{21}$.

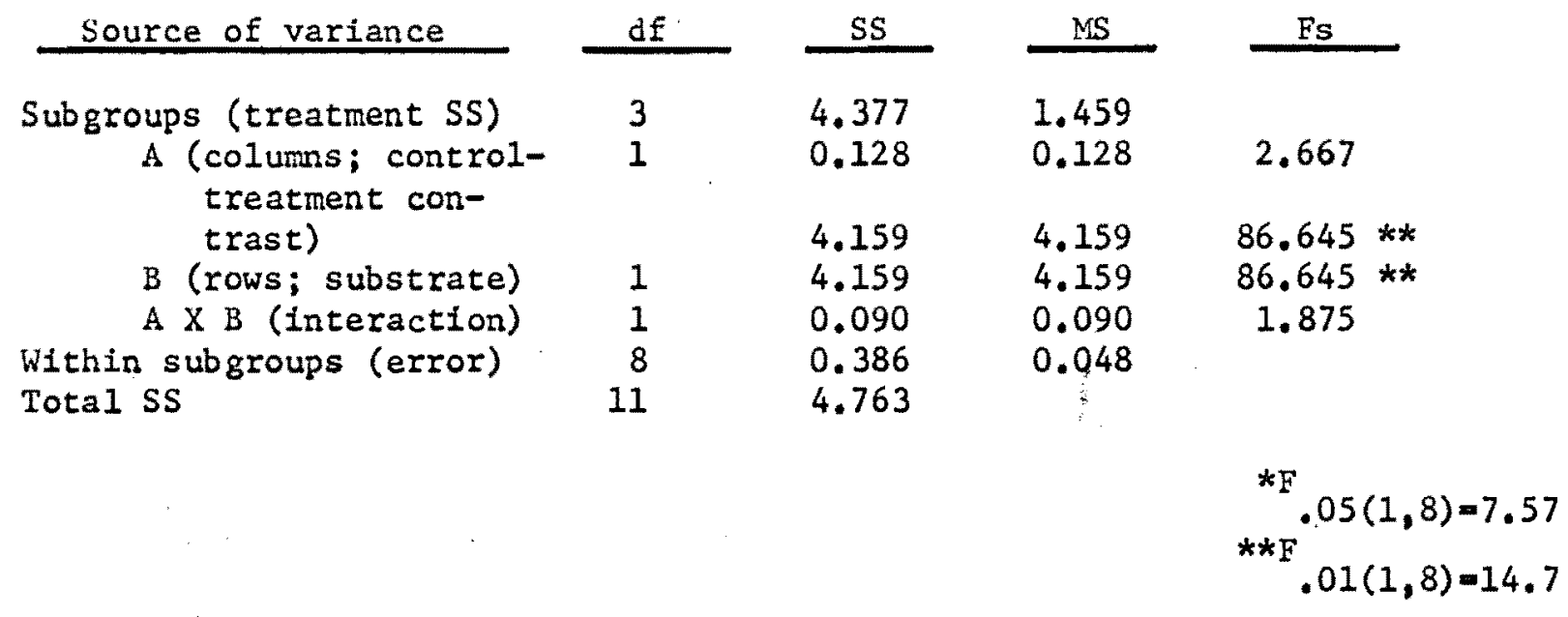

ANOVA Table 12

COMPUTED VALUES REFER TO NUMBER OF GERMINATED SEEDS

OF B. TECTORUM IN TRIAL NUMBER THREE LOCATED IN TABLE

V, PG. 21.

\begin{tabular}{|c|c|c|c|c|}
\hline Source of variance & $d f$ & SS & $\mathrm{MS}$. & Fs \\
\hline $\begin{array}{l}\text { Subgroups (treatment SS) } \\
\text { A (columns; control- } \\
\text { treatment con- } \\
\text { trast) }\end{array}$ & $\begin{array}{l}3 \\
1\end{array}$ & $\begin{array}{l}0.793 \\
0.177\end{array}$ & $\begin{array}{l}0.264^{\circ} \\
0.177\end{array}$ & 0.756 \\
\hline $\begin{array}{l}\text { B. (rows; substrate) } \\
\text { A X B (interaction) } \\
\text { Within subgroups (error) } \\
\text { Total SS }\end{array}$ & $\begin{array}{r}1 \\
1 \\
8 \\
11\end{array}$ & $\begin{array}{l}0.380 \\
0.236 \\
1.874 \\
2.667\end{array}$ & $\begin{array}{l}0.380 \\
0.236 \\
0.234\end{array}$ & $\begin{array}{l}1.624 \\
1.008\end{array}$ \\
\hline
\end{tabular}

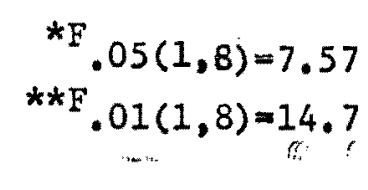

